\title{
DIFFERENT EFFECTS OF PENTOBARBITAL AND PENTYLENETETRAZOL ON NITRIC OXIDE LEVELS IN RAT FRONTAL CORTEX
}

\author{
DŽOLJIĆ ELEONORA, NEŠIĆ ZORICA, STOJANOVIĆ R, TODOROVIĆ Z, VUČKOVIĆ SONJA, \\ DELIĆ D, IVANOVIĆ M and PROSTRAN MILICA
}

School of Medicine, Belgrade, Belgrade

(Received 14. February 2005)

Levels of nitric oxide (NO) in the rat's frontal cortex were continuously monitored before and after intraperitoneal administration of an antiepileptic drug-pentobarbital (20 and $40 \mathrm{mg} / \mathrm{kg}$ ) or convulsant drug - pentylenetetrazol (50 mg/kg). Pentobarbital decreased the levels of NO in a dose dependent manner. However, NO levels had a tendency to increase following the administration of pentylenetetrazol. It is suggested that central NO participates in the modulation of neuronal excitability, supporting the idea that NO is an important excitatory factor involved in the regulation of seizure susceptibility. Also, our results on anaesthetized rats suggests that endogenous NO may be involved in the mechanism of action of antiepileptic and analeptic drugs and this further suggest that NO levels in the human brain may decrease during antiepileptic therapy and increase during epileptic attacks or administration of excitatory drugs.

The aim of the present study was to determine the possible role of NO levels in the brain during neuronal excitability and seizures.

Key words: nitric oxide levels, pentobarbital, pentylenetetrazol, rat frontal cortex

\section{INTRODUCTION}

Epilepsy is a common and heterogeneous neurological disorder arising from biochemical and molecular events that are not completely understood. To effectively manage epilepsy, it is important to understand the mechanisms underlying both seizure-induced brain damage as well as seizure initiation (Patel et al., 2002).

Experimental data indicate that nitric oxide (NO) may play a role in the pathophysiology of epilepsy: it is also possible that NO-mediated events are involved in the expression of the anticonvulsant action of some antiepileptics (Wojtal et al., 2003). NO plays a key role in neurotransmission, acting as a mediator controlling neuronal signalling, cGMP levels and release of several neurotransmitters (Bredt et al., 1990; Garthwaite, 1991). Also, NO has been involved in the regulation of neuronal excitability and seizure threshold, thus 
stimulating the release of three main excitatory neurotransmitters such as aspartate (Guevara-Guzman et al., 1994), glutamate (Guevara-Guzman et al., 1994; Montague et al., 1994) and noradrenaline (Montague et al., 1994).

The precise mechanisms of NO in the expression of seizure is unclear and controversial (Kirkby et al., 1996; Rundfelt et al. 1995; Van Leeuwen et al., 1995; De Sarro et al., 1991). However, levels of NO in the brain could be used as an important parameter to clarify the role of NO in epileptic phenomena. Therefore, we measured NO levels in the rats' frontal cortex following administration of pentobarbital and pentylenetetrazol, selected as representatives of anticonvulsant and proconvulsant drugs.

\section{MATERIALS AND METHODS}

\section{Animals and surgery}

The experiments were performed on adult male Wistar rats (340-360 g). Rats were bred and kept under ordinary laboratory conditions. The investigation conforms to the Guide for the care and use of laboratory animals published by the US National Institutes of Health (NIH publication No. 85-23, revised 1985). The experimental procedure was approved by the Regional Ethical Committee. Rats were divided in 4 equal groups and anaesthetized by intraperitoneal administration of $0.15 \mathrm{ml} / \mathrm{kg}$ solution of Hypnorm ${ }^{\mathrm{R}}$ (fentanyl citrate $0.315 \mathrm{mg} / \mathrm{ml}$ and fluanisone $10 \mathrm{mg} / \mathrm{ml}$, Janssen Pharmaceuticals, Beerse, Belgum) $(0.15 \mathrm{ml}$ contains $0.0472 \mathrm{mg}$ fentanyl citrate plus $0.15 \mathrm{mg}$ fluanisone per $\mathrm{kg}$ ) prior to pentobarbital treatment. In the case of pentylenetetrazol treatment, pentobarbital sodium $(60 \mathrm{mg} / \mathrm{kg})$ was used as the anaesthetic drug. The rats were artificially ventilated with a frequency of $70 / \mathrm{min}$, maintaining constant $p \mathrm{O}_{2}$ and $p \mathrm{CO}_{2}$. Experiments were performed in the laboratory at constant room temperature (21.0 $\pm 1.0^{\circ} \mathrm{C}$ ) and humidity (55\%), while the rectal temperature of the animals was maintained at $37.0 \pm 0.5^{\circ} \mathrm{C}$ with a heating pad. The head of the animal was mounted in the stereotaxic head holder and a hole was drilled into the right frontal region of the skull. After slicing the dura, a sensor for the detection of NO was stereotaxically implanted perpendicular to the right cortex at coordinates: $2 \mathrm{~mm}$ lateral, $2 \mathrm{~mm}$ anterior to bregma and $2 \mathrm{~mm}$ below the dura. A ground electrode was placed subcutaneously in the animals' neck. In order to prevent convulsions, animals treated with pentylentetrazol were injected with d-tubocurarine $(0.1 \mathrm{mg} / \mathrm{kg}$, i.p.). Cortical levels of $\mathrm{NO}$ were continuously monitored before and after intraperitoneal administration of drugs.

\section{NO measurement}

NO measuring system was an Isolated Nitric Oxide Meter (ISO-NO Mark II made by World Precise Instrument, Inc. Sarasota, Florida, USA) with amperometric micro-sensor (tip diameter: $200 \mu \mathrm{m}$ ) - ISO-NOP 200 also made by World Precise Instrument, Inc. Sarasota, Florida USA. This electrochemical microprobe method using amperometric sensors has frequently been employed to detect quantitative changes of NO levels in different tissues in vivo (Zhang et al., 
2000; Stefano et al., 2002, Foresti et al., 2003; Badzynska et al., 2004). ISO-NO Meter II is sufficiently sensitive and selective to detect the release of NO in the brain tissue (Shibuki, 1990) but without altering the electrophysiological recording of basal cell firing during in vivo experiments (Crespi et al., 1994). Briefly, NO diffuses through a semipermeable membrane and is than oxidized on a working platinum electrode resulting in an electric current. This redox current is proportional to the level of NO at the membrane's surface. The output current of the probe correlates linearly with the NO level at the tip (Shibuki, 1990; Engelman et al., 1995). The electrode calibration was done daily before each experiment and sensitivity was $1.1 \mathrm{pA} / \mathrm{nM}$ change in NO level. Calibration was obtained by measuring the current generated by the $10 \mu \mathrm{M} N O$ in aqueous solution, prepared by adding saturated NO solution to $120 \mathrm{ml} 0.9 \%$ saline under strict inert atmosphere and stored in an all-glass container with a small head space. The probe showed no sensitivity to oxygen or to oxidized derivatives of NO (Zhang et al., 2000). The output of the amplifier was connected to a chart recorder. Due to significant interindividual variations in absolute NO levels, the data were expressed as percentage difference from relatively stable NO level before drug administration. After NO baseline level was reached, the animals were injected i.p. with the drug or vehicle. Recording of the current continued for the next 60 minutes. The NO levels for each experiment were calculated by comparing the current measured from experimental amperometric curve with the current obtained after calibration with NO solution. On completion of the experiments, animals were killed with a high dose of sodium pentobarbital.

\section{Statistical evaluation}

Statistical analysis was carried out using GraphPad Prism/Instat 1.1 (GraphPad Software, California, USA) using one-way analysis of variance (ANOVA) followed by Dunnett's post-significance testing. A $P$ value of less than 0.05 was considered significant.

\section{Drugs}

The following drugs were used: Hypnorm ${ }^{\circledR}$ (fentanyl citrate $0.315 \mathrm{mg} / \mathrm{ml}$ plus fluanisone $10 \mathrm{mg} / \mathrm{ml}$, Janssen Pharmaceuticals, Beerse, Belgum), Nembutal $^{\circledR}$ (pentobarbital sodium, solution $60 \mathrm{mg} / \mathrm{ml}$, Eppendorf, Hamburg, Germany), Pentylenetetrazol ${ }^{\circledR}$ (Sigma-Aldrich Company Ltd., Poole, Dorset, UK), d-tubocurarine chloride hydrate ${ }^{\circledR}$ (Sigma-Aldrich Company Ltd., Poole, Dorset, UK). All drugs were dissolved in non-pyrogenic saline $(0.9 \% \mathrm{NaCl}$; Baxter Healthcare Ltd., Thetford, Norfolk, UK). Drug solutions were prepared prior to application. The doses of pentylenetetrazol and pentobarbital used in this study are known to exert proconvulsant and anticonvulsant effects in rats, respectively. Pentylenetetrazol was administered in a convulsant dose of $50 \mathrm{mg} / \mathrm{kg}$, which induced clonic-tonic convulsions in all animals. Pentobarbital in doses of $20 \mathrm{mg} / \mathrm{kg}$ and $40 \mathrm{mg} / \mathrm{kg}$ exerted known anticonvulsant or anaesthetic effects, respectively. 


\section{RESULTS}

Levels of NO in the frontal cerebral cortex of anaesthetized rats were continuously monitored during the baseline period of 1-2 $\mathrm{h}$ (period of stabilisation). During this period, NO levels were $2.2 \pm 1.3 \mu \mathrm{M}$ (mean \pm S.E.M.) (range 0.5-4.6 $\mu \mathrm{M})$. In control animals $(n=5)$, treated only with the vehicle solution i.e. non-pyrogenic saline $(0.9 \% \mathrm{NaCl})$, a slow but not significant decline in brain level of NO during the first hour of the experiment was registered. However, the decline of $\mathrm{NO}$ level continued in the following hours of the experiment until the animals died. Therefore, the comparison between brain NO levels in control animals (treated with vehicle solution) and drug treated animals was in our experiment limited to the first 60 minutes after drug injection. Administration of pentobarbital (20 and $40 \mathrm{mg} / \mathrm{kg}$ ) induced a significant and dose-dependent decrease of the brain NO level compared to the control group. In contrast, administration of a convulsant dose of pentylenetetrazol $(50 \mathrm{mg} / \mathrm{kg})$ significantly increased frontal cortex level of $N O(P<0.05)$ in comparison with the control group, 30 minutes after administration of the drug (Figure 1).

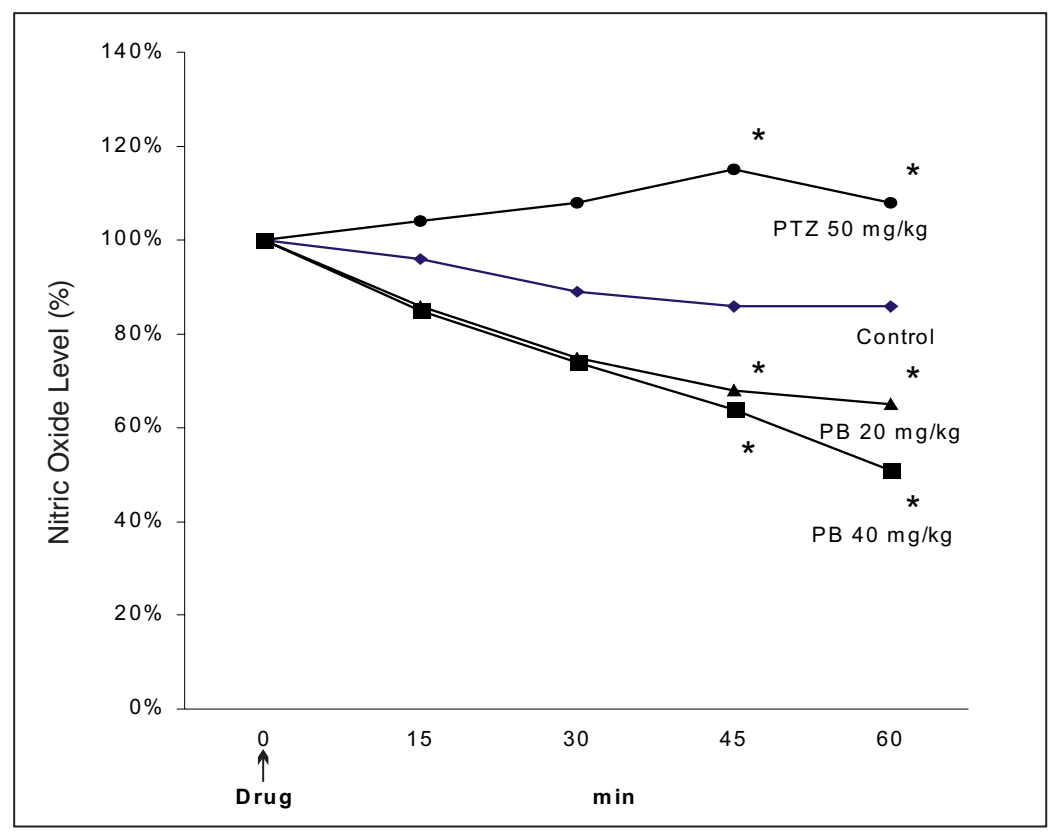

Legend: - -: Control; -•-: PTZ (50 mg/kg); - ^-: PB (20 mg/kg); - -:: PB (40 mg/kg);

Figure 1. Nitric oxide (NO) levels in rat frontal cortex, measured by electrochemical microprobe (ISO-NO II), before and after intraperitoneal administration of pentobarbital (PB, 20 and $40 \mathrm{mg} / \mathrm{kg}, \mathrm{n}=5)$, pentylenetetrazol (PTZ, $50 \mathrm{mg} / \mathrm{kg}, \mathrm{n}=5$ ) or vehicle-control $(0.5 \mathrm{ml}, \mathrm{n}=5)$. Levels of $\mathrm{NO}$ were expressed as percentage difference to relatively stable NO level when the drug was administered $(t=0$; denoted as $\uparrow)$. Asterisk $\left({ }^{*}\right)$ represents a significant difference in comparison with control $(P<0.05$; ANOVA followed by Dunnet' test). 
Acta Veterinaria (Beograd), Vol. 55. No. 5-6, 367-374, 2005.

\section{DISCUSSION}

Baseline levels of NO registered in rat frontal cortex in this study $\left(\sim 10^{-6} \mathrm{M}\right)$ correlate with $\mathrm{NO}$ levels found in the rat frontal cortex throughout the sleep-waking cycle (Burlet et al., 1995) and in the rat parietal cortex during middle cerebral artery occlusion (Zhang et al., 1995). These two studies report that baseline NO levels are lower $\left(\sim 10^{-8} \mathrm{M}\right)$ compared with the baseline NO levels found in our study. This may be due to different experimental conditions, such as different anaesthetics used (fentanyl citrate plus fluanisone in our study vs. ketamine and xylazine), different levels of anaesthesia with corresponding difference in cerebral blood flow (which affects NOS activity) and/or different locations of the working electrodes (frontal cortex in our study vs. parietal cortex). Spontaneous, but not statistically significant decrease of brain NO levels in the first hour in control animals is probably due to the applied anaesthesia (Allimoff and Miller, 1993; Tobin et al., 1994). Also, it is probably a result of the decline in vital functions and central blood flow in experimental animals.

The main finding in our study is that anticonvulsant and proconvulsant drugs affect the NO levels in rat frontal cortex in vivo in opposite ways: anticonvulsant pentobarbital decreases and proconvulsant PTZ increases the NO levels. Many studies show that pentobarbital and other antiepileptics decrease levels of NO in the cerebral cortex and it is also possible that NO is involved in the anticonvulsant action of antiepileptics (Wojtal et al., 2003; Borowicz et al., 1997). Borowicz et al. (1997) have shown that 7-nitroindazole decreased NO level in brain. Such effect may be responsible for the anticonvulsive action of 7nitroindazole in certain models of epilepsy and for the protective activity of pentobarbital against electroshock-induced convulsions in mice. At the same time, 7-nitroindazole did not affect anticonvulsive activity of other antiepileptic drugs, such as carbamazepine, diphenylhydantoin and valproate. Anticonvulsive properties of pentobarbital are mainly due to the potentiation of $\mathrm{GABA}_{\mathrm{A}}$ receptor mediated effects and inhibition of glutamate activity (Haefely, 1980). It is known that barbiturates also decrease cGMP formation in many brain regions (Kant et al., 1980). This may explain a decrease of NO levels following administration of pentobarbital. Many studies have shown that NOS inhibitors exert anticonvulsant activity (Mollace et al., 1991; De Sarro et al., 1991; Zhang et al., 1993; Osonoe et al., 1994; Przewlocka et al., 1994; Mülsch et al., 1994; Nakamura et al., 1995; Becker et al., 1995; Van Leeuwen et al., 1995; Kirkby et al., 1996; Dzoljic et al., 1996). This study indicates that a decrease of neuronal excitability following barbiturates may be due, at least partially, to low levels of endogenous NO. Evidently, the decrease of neuroexcitability and corresponding increase of seizure threshold following administration of pentobarbital is due to activation of GABA inhibitory pathways and reduction of NO transmission, in conjunction with a decrease in the release of excitatory amino acids and NO production. Therefore, involvement of decreased brain NO levels in the mechanism of action of barbiturates (or other anticonvulsant) drugs deserves serious consideration.

Pentylenetetrazol (PTZ), a GABA ${ }_{A}$ receptor antagonist has been extensively utilized in animal models of seizures. Several classes of compounds can modulate the PTZ discriminative stimulus including 5-HT (1A), 5- HT(3), NMDA, glycine, and L-type calcium channel ligands (Jung et al., 2002). It has been shown 
that PTZ proconvulsant activity is mediated by activation of NMDA receptors, leading to increase of cGMP levels in the brain. Also, PTZ induces oxidative damage in brain tissue by increasing the production of reactive oxygen species (Ilhan et al., 2004). These effects were considered as important factors for seizure onset and propagation (Ferrendely et al., 1980; Jiang et al., 2004). Because NMDA receptor activation stimulates NO (Garthwaite et al., 1989; East and Garthwaite, 1991), it seems that increased neuroexcitability following pentylenetetrazol administration is, at least partially, due to the activation of glutaminergic transmission and increase of NO levels. Itoh et al. (2004) studied the role of NO in the development of PTZ-kindling as an animal model of primary generalized epilepsy. They found that a daily administration of PTZ is associated with an increase in the amount of neuronal nitric oxide synthase (nNOS). NO generation was measured directly by in vivo and ex vivo electron paramagnetic resonance on rodents undergoing progressive convulsions. They found that primary generalized epilepsy is caused by NO induction during the persistent upregulation of $\mathrm{nNOS}$ expression. Severe generalized seizures following PTZ withdrawal are not associated with NO production. Also, they reported that cerebellum volume for kindled rats decreased $20 \%$, but not in rats treated with the nNOS inhibitor, 3Br-7-nitroindazole, suggesting that generation of $\mathrm{NO}$ in the cerebellum is related to decrease in cerebellum volume following PTZ-kindling.

However, increase in NO levels by pentylenetetrazol in our study is not as high as would be expected probably due to prior administration of pentobarbital in anaesthetic dose $(60 \mathrm{mg} / \mathrm{kg})$, known to block glutaminergic transmission and release excitatory amino acids (Alifimoff and Miller, 1993). It seems that future experiments with unanaesthetized animals could clarify the positive interactions between excitatory drugs and brain NO levels.

In conclusion, these results indicate that NO levels in the frontal cortex of the central nervous system in anaesthetized rats are decreased by pentobarbital and increased following administration of pentylenetetrazol. This study shows that NO levels in the brain are related to neuronal excitability, indicating an important modulatory role of NO in the regulation of seizure susceptibility.

Address for correspondence:

Prof. Dr Milica Prostran

Department of Pharmacology, Clinical Pharmacology and Toxicology

School of Medicine University of Belgrade

Dr Subotića 1

11000 Belgrade, Serbia\& Montenegro

E-mail: znesic@yahoo.com

\section{REFERENCES}

1. Alifimoff JK, Miller KW, 1993, Mechanisms of action of general anaesthetic agents, In: Rogers MC, Tinker JH, Covino BG, Longnecker DE, editors, Principles and Practice of Anaesthesiology, St. Louis: Mosby-Year Book, 1034-52.

2. Badzyska B, Grzelec-Mojzesowicz M, Sadowski J, 2004, Effect of exogenous angiotensin II on renal tissue nitric oxide and intrarenal circulation in anaesthetized rats. Acta Physiologica Scandinavica, 182, 313-8. 
3. Becker A, Gresch G, Schröder H, 1995, N-omega-nitro-L-arginine methyl ester interferes with pentylenetetrazol-induced kindling and has no effect on changes in glutamate binding. Brain Res, 688, 230-2.

4. Bredt DS, Hwang PM, Snyder SH, 1990, Localization of nitric oxide synthase indicating a neuronal role for nitric oxide. Nature, 34, 768-70.

5. Borowitz, KK, Kleinrok, Z, Czuczwar, SJ, 1997, Influence of 7-nitroindazole on anticonvulsive action of conventional antiepileptic drugs. Eur J Pharmacol, 331, 127-32.

6. Crespi E, England T, Ratti E, Trist DG, 1995, Carbon fibre micro-electrodes for concomitant in vivo electrophysiological and voltimetric measurements: no reciprocal influences. Neurosci Lett, 188, 33-5.

7. De Sarro GB, Di Paola ED, De Sarro A, Vidal MJ, 1991, Role of nitric oxide in the genesis of excitatory amino acid-induced seizures from the deep prepiriform cortex. Fundam Clin Pharmacol 5, 50311.

8. Dzoljic MR, De Vries $R$, Van Leeuwen $R, 1996$, Sleep and nitric oxide: effects of 7-nitro indazole, inhibitor of brain nitric oxide synthase. Brain Res 718, 145-50.

9. East SJ, Garthwaite J, 1991, NMDA receptor activation in rat hippocampus induces cyclic GMP formation through the L-arginine-nitric oxide pathway. Neurosci Lett, 123, 17-9.

10. Engelman DT, Watanabe M, Engelman RM, Rousou JA, Flack JE, Deaton DW, Das DK, 1995, Constitutive nitric oxide release is impaired after ischemia and reperfusion. $J$ Thorac Cardiovasc Surg, 110, 1047-53.

11. Ferrendelli JA, Blank AC, Gross RA, 1980, Relationship between seizure activity and cyclic nucleotide levels in brain. Brain Res, 200, 93-103.

12. Foresti R, Hoque M, Bains S, Green CJ, Motterlini R, 2003, Haem and nitric oxide: synergism in modulation of the endothelial haem oxygenase-1 pathway. Biochem J, 372, 281-90.

13. Garthwaite J, Garthwaite G, Palmer RMJ, Moncada S, 1989, NMDA receptor activation induces nitric oxide synthesis from arginine in rat brain slices. Eur J Pharmacol, 172, 413-6.

14. Garthwaite J, 1991, Glutamate, nitric oxide and cell-cell signalling in the nervous system. Trends Neuro Sci, 14, 60-7.

15. Guevara-Guzman R, Emson PC, Kenderick KM, 1994, Modulation of in vivo striatal transmitter release by nitric oxide and cyclic GMP. $J$ Neurochem, 62, 807-10.

16. Haefely WE, 1980, GABA and the anticonvulsant action of benzodiazepines and barbiturates. Brain Res Bull, 5 (Suppl. 2), 873-7.

17. Ilhan A, Iraz M, Gurel A, Armutcu F, Akyol O, 2004, Caffeic acid phenethyl ester exerts a neuroprotective effect on CNS against pentylenetetrazol-induced seizures in mice. Neurochem Res, 29, 2287-92.

18. Itoh K, Watanabe M, Yoshikawa K, Kanaho Y, Berliner LJ, Fujii H, 2004, Magnetic resonance and biochemical studies during pentylenetetrazole-kindling development: the relationship between nitric oxide, neuronal nitric oxide synthase and seizures. Neuroscience, 129, 757-66.

19. Jiang W, Xiao L, Wang JC, Huang YG, Zhang X, 2004, Effects of nitric oxide on dentate gyrus cell proliferation after seizures induced by pentylenetrazol in the adult rat brain. Neurosci Lett, 367 , 344-8.

20. Jung ME, Lal H, Gatch MB, 2002, The discriminative stimulus effects of pentylenetetrazol as a model of anxiety: recent developments. Neurosci Biobehav Rev, 26, 429-39.

21. Kant GJ, Muller TW, Lenoxd RH, Meyerhoff JL, 1980, In vivo effects of pentobarbital and halothane anaesthesia on levels of adenosine 3',5'-monophosphate and guanosine 3',5'-monophosphate in rat brain regions and pituitary. Biochem Pharmacol, 29, 1891-6.

22. Kirkby RD, Carroll DM, Grossman AB, Subramaniam S, 1996, Factors determining proconvulsant and anticonvulsant effects of inhibitors of nitric oxide synthase in rodents. Epilepsy Res, 24, 91100.

23. Mollace V, Bagetta G, Nisticò G, 1991, Evidence that L-arginine possesses proconvulsant effects mediated through nitric oxide. Neuroreport, 2, 269-72.

24. Montague PR, Gancayco CD, Winn MJ, Marchase RB, Friedlander MJ, 1994, Role of NO production in NMDA receptor-mediated neurotransmitter release in cerebral cortex. Science, 263, 973-7. 
25. Mülsch A, Busse R, Mordvintcev PJ, Vanin AF, Nielsen EO, Schcel-Krüger J, Olesen SP, 1994, Nitric oxide promotes seizure activity in kainate-treated rats. Neuroreport, 5, 2325-8.

26. Nakamura TA, Yamada K, Hasegawa T, Nabeshima T, 1995, Possible involvement of nitric oxide in quinolinic acid-induced convulsions in mice. Pharmacol Biochem Behav, 51, 309-12.

27. Osonoe K, Mori N, Suzuki K, Osonoe M, 1994, Antiepileptic effects of inhibitors of nitric oxide synthase examined in pentylenetetrazol-induced seizures in rats. Brain Res, 663, 338-40.

28. Patel MN, 2002, Oxidative stress, mitochondrial dysfunction, and epilepsy. Free Radic Res, 36, 1139-46.

29. Przewlocka B, Lason W, Machelska H, Przewlocki R, 1994, The effects of cocaine-induced seizures on the proenkefalin mRNA in the mouse hippocampus: a possible involvement of the nitric oxide pathway. Neurosci Lett, 168, 81-4.

30. Rundfeld C, Koch R, Richter A, Mevissen M, Gerecke U, Löschhner W, 1995, Dose-dependent anticonvulsant and proconvulsant effects of nitric oxide synthase inhibitors on seizure threshold in a cortical stimulation model in rats. Eur J Pharmacol, 274, 73-81.

31. Shibuki K, 1990, An electrochemical microprobe for detecting nitric oxide release in brain tissue. Neurosci Res, 9, 69-76.

32. Stefano G, Salzet M, Magazine H, 2002, Cyclic nitric oxide release by human granulocytes, and invertebrate ganglia and immunocytes: nano-technological enhancement of amperometric nitric oxide determination. Med Sci Monit, 8, 199-204.

33. Van Leeuwen R, De Vries R Dzoljic MR, 1995, 7-Nitro indazole, an inhibitor of neuronal nitric oxide synthase, attenuates pilocarpine-induced seizures. Eur J Pharmacol, 287, 211-3.

34. Zhang J, Su Y, Oury TD, Piantadosi CA, 1993, Cerebral amino acid, norepinephrine and nitric oxide metabolism in CNS oxygen toxicity. Brain Res, 606, 56-62.

35. Zhang ZG, Chop M, Bailey F, Malinski T, 1995, Nitric oxide changes in rat brain after transient middle cerebral occlusion. J Neurol Sci, 128, 22-7.

36. Zhang X, Cardosa L, Broderick M, Fein H, Lin J, 2000, An integrated nitric oxide sensor based on carbon fiber coated with selective membranes. Electroanalysis, 12, 1113-7.

37. Wojtal K, Gniatkowska-Nowakowska A, Czuczwar SJ, 2003, Is nitric oxide involved in the anticonvulsant action of antiepileptic drugs? Pol J Pharmacol, 55, 535-42.

\title{
UTICAJ PENTOBARBITALA I PENTILENETETRAZOLA NA NIVO AZOT OKSIDA U FRONTALNOM KORTEKSU PACOVA
}

\author{
DŽOLJIĆ ELEONORA, NEŠIĆ ZORICA, STOJANOVIĆ R, TODOROVIĆ Z, \\ VUČKOVIĆ SONJA, DELIĆ D I PROSTRAN MILICA
}

\section{SADRŽAJ}

Nivo azot oksida (NO) u frontalnom korteksu pacova meren je kontinuirano kako pre, tako i nakon intraperitonealne primene antiepileptika pentobarbitala (u dozi od 20 i $40 \mathrm{mg} / \mathrm{kg}$ ) ili konvulzivnog agensa pentilenetetrazola (u dozi od $50 \mathrm{mg} / \mathrm{kg}$ ). Rezultati ovih eksperimenta su ukazali da pentobarbital smanjuje nivo NO u frontalnom korteksu pacova, dok koncentracija NO ima tendeciju rasta nakon primene pentilenetetrazola. Osim toga, dokazano je da endogeni NO ima važnu ekscitatornu ulogu u centralnim mehanizmima nastanka epilepsije. Takođe, naši rezultati su ukazali da kod anestetisanih životinja endogeni nivo NO ima uticaja na dejstvo kako antikonvulzivnih, tako i prokonvulzivnih lekova. Nivo NO u mozgu pacova je bio snižen tokom terapije antiepilepticima, a povišen tokom epileptičkih napada ili primene lekova iz grupe centralnih stimulansa. 